\title{
La pandemia que afectó a todos...
}

\author{
The pandemic that affect everyone and everything
}

\author{
Juan Carlos Gómez Mireles*
}

Después de una larga pausa que suscitó la aparición del virus llamado SARS-CoV-2 causante de la enfermedad COVID-19 en el ámbito laboral, económico y cultural, por mencionar algunos, parece que el mundo entero comienza a retomar rumbo hacia una «nueva normalidad», por lo que nos preguntamos: ¿qué nos espera a corto, mediano y largo plazo como profesionales de la salud bucal?

Aún en 2021, nos encontramos atravesando la pandemia sin una idea exacta de cuándo este sinuoso camino llegará su fin, pues sabemos que esta enfermedad ha llegado para establecerse y permanecer con nosotros por un largo tiempo. Desde su origen supuso una amenaza latente para la salud mundial y planteó la importancia del campo de bioseguridad, reafirmando la necesidad del uso de barreras de protección. Como profesionales de la salud bucal, nos cuestionamientos sobre la dirección que tomará nuestra práctica odontológica, puesto que, de acuerdo con las características de nuestra profesión, el riesgo de infecciones cruzadas es sumamente elevado, ya que trabajamos en contacto directo con el principal vehículo transmisor del mortal virus, por lo que será entonces un gran reto, además de una gran responsabilidad, prestar nuestros servicios salvaguardando nuestra salud, la de nuestro equipo de trabajo, pacientes y comunidad entera.

La propagación del virus desde finales de 2019, cuando se describió el caso cero en la Ciudad de Wuhan, China, fue vertiginosa; facilitado por los múltiples viajes internacionales realizados día con día, la enfermedad se propagó hacia todas partes y fue en febrero de 2020 cuando se diagnosticó el primer caso en nuestro país.

En un intento por continuar con nuestra consulta diaria, se comenzaron a «re-implementar» distintos protocolos de seguridad: uso de cubrebocas, lentes de protección, careta, lavado de manos continuo, desinfectantes, trajes quirúrgicos, batas y gorros desechables, entre muchas otras cosas, entrecomillo «re-implementar» porque todos estos protocolos de bioseguridad, como odontólogos, los aprendimos en la universidad, pero que, a través del paso

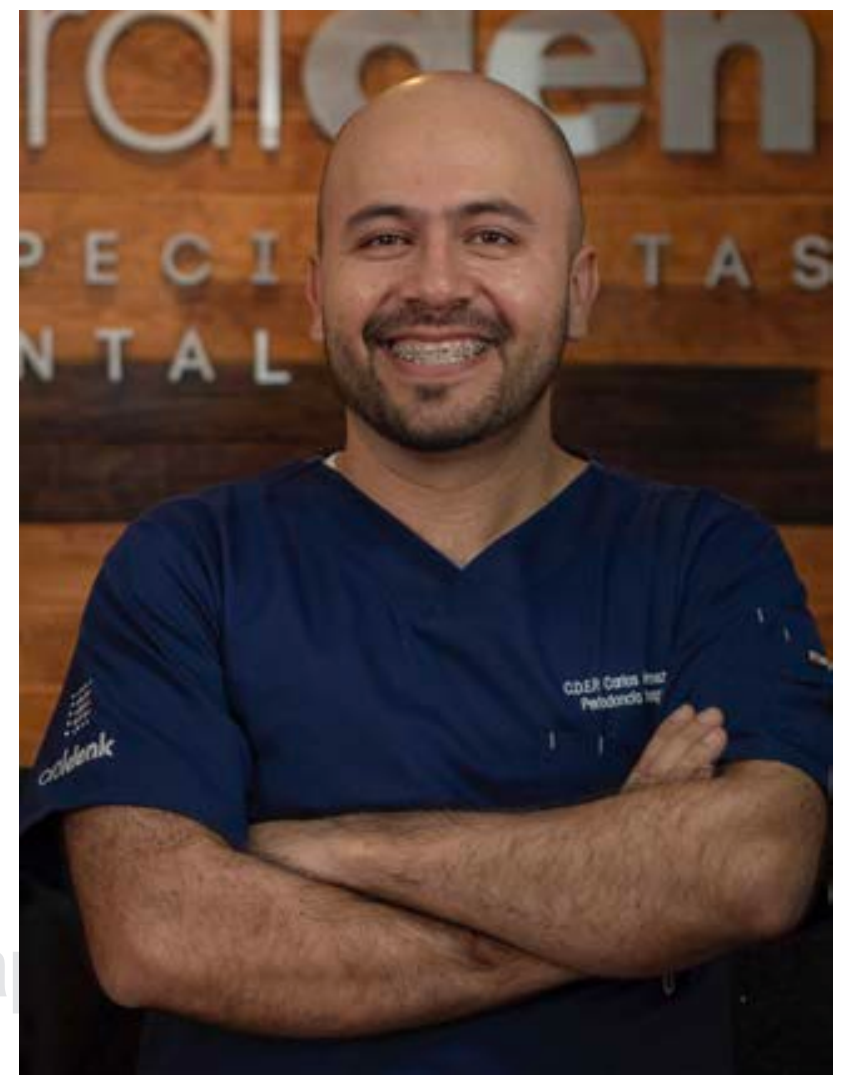

Figura 1: M. en C. Juan Carlos Gómez Mireles.

\section{Especialista en Periodoncia, Centro Universitario de Ciencias de la Salud, Universidad de Guadalajara.}

Citar como: Gómez MJC. La pandemia que afectó a todos... Rev Mex Periodontol. 2021; 12 (1-3): 5-6. https://dx.doi.org/10.35366/102952 
del tiempo, fuimos dejando de lado, exponiéndonos más y más a las enfermedades infecto-contagiosas.

Para algunos de nosotros, odontólogos generales y especialistas, es un gran alivio que el uso de estas barreras de protección y medidas de bioseguridad siguen siendo algo cotidiano, y podemos darnos cuenta de que, como gremio, estábamos ya «preparados» para enfrentar esta enfermedad comparados con otras profesiones, donde el contacto persona-persona es algo de todos los días sin el uso de estas medidas de seguridad. El mayor problema con el cual nos enfrentamos al momento de ejercer nuestra profesión es la dispersión de aerosoles ocasionados por el uso de la pieza de mano, instrumentos ultrasónicos, aeropulidores o incluso la jeringa triple. Recomendado por la Organización Mundial de la Salud se hizo común la utilización de colutorios como la clorhexidina y peróxido de hidrogeno antes de comenzar los tratamientos odontológicos o periodontales con el objetivo de disminuir la carga viral en caso de que el paciente fuera positivo a COVID. Retomó importancia el aislamiento absoluto, que si bien ya tenía algún tiempo siendo moda entre el gremio, ahora fue necesario con el fin de evitar contagios; pues al aislar el órgano dentario de la cavidad oral, se evita el contacto con la saliva del paciente.
El desarrollo de la vacuna vino a dar tranquilidad a muchos, e intranquilidad a otros, pues no tardaron en aparecer las noticias alarmistas de conspiraciones por todos lados, que gracias a las redes sociales y escasos filtros de información establecidos para ellas se viralizaron, y en muchos casos eran falsas fabricadas con el objetivo de la desinformación.

La llegada de esta enfermedad, declarada pandemia, además de los numerosos decesos, incertidumbre, miedo, paranoia y estrés, también nos deja mucho aprendizaje a nivel personal, pues nos devuelve a nuestros inicios, nos enseña a apreciar la vida, nos obligó a tomar una pausa, a valorar nuestro tiempo, a recordarnos lo importante que es estar en casa con los nuestros, a reencontrarnos con nosotros mismos. Además, a nivel profesional, nos recuerda que contamos con herramientas para evitar contagios y ejercer nuestra profesión de manera segura, lo que nos permite seguir haciendo lo que amamos, ejercer la bella rama de la odontología: la Periodoncia; brindándonos esa alegría de cuidar y devolver las sonrisas a la sociedad (Figura 1).

\author{
Correspondencia: \\ Juan Carlos Gómez Mireles \\ E-mail: carlosperioudg@hotmail.com
}

